\title{
AC 2011-555: ACTIVE AND COOPERATIVE LEARNING ACTIVITIES FOR AN INTRODUCTORY BIOMATERIALS COURSE
}

\section{Jennifer Vernengo, Rowan University}

Jennifer Vernengo is an Assistant Professor of Chemical Engineering at Rowan University. Jennifer received her Ph.D. from Drexel University in 2007. She began work as a materials scientist at Synthes Biomaterials, then joined Drexel University College of Medicine as postdoc in 2009. Jennifer two published research papers and one patent in the area of injectable biomaterials for orthopedic tissue replacement and repair. She is particularly interested in developing innovative approaches to biomedical engineering education. 


\title{
Active and Cooperative Learning Activities for Introducing Undergraduate Students to Biomaterials
}

\begin{abstract}
Biomaterials science is a relatively new interdisciplinary field. Because of the increasing prevalence of musculoskeletal, cardiovascular, and neurodegenerative diseases, there is a necessity to engineer biomaterials that can be used to treat these painful and debilitating disorders. The overall objective of this initiative is to teach our undergraduate students concepts in the research, development, and clinical application of biomaterials. Two open-ended laboratory activities, one developed for freshman and the other for seniors, are presented here that involve the design of biomaterials for cartilage and bone replacement. An assessment plan, to be executed during Spring 2011, will measure student mastery of learning outcomes specific to the field of biomaterials science and those set forth by ABET for undergraduate Chemical Engineering programs.
\end{abstract}

\section{Introduction}

Biomaterials have received considerable attention over the past 30 years. A biomaterial has been defined as a material intended to interface with a biological system to evaluate, treat, augment, or replace any tissue organ or function in the body (1). Therefore, the study of biomaterials encompasses the study of materials science, medicine, and biology. It is estimated that over 11 million people have implants utilizing engineered biomaterials (2). In addition, 82 billion dollars were spent on research and development within this field in the United States in 2001 (3). Because of the increasing care requirements of an aging population, educational institutions need to provide specialized education in this area (4). In this paper, we describe a freshman-level laboratory on the design of ceramic-polymer composites for bone replacement and a senior-level laboratory on the design of hydrogels for cartilage replacement.

The modules described in this paper employ methods of active learning, where students apply important STEM principles to the design of systems that can treat debilitating diseases by repairing, replacing, or augmenting tissues. The objectives of these activities, specific to the field of biomaterials are to 1) introduce students to clinically applied biomaterials, 2) allow students to actively experience current biomaterials research methods, 3) develop students' ability to read, analyze, and critique relevant literature, 4) teach students inter-relationships between biomaterial structure, properties, and medical device functionality, and 5) teach students how to design a biomaterial to achieve the desired healing response from the body. Additionally, the modules were designed to contribute to certain ABET outcomes for students graduating with a bachelors of science in Chemical Engineering. These outcomes include 1) an ability to apply knowledge of mathematics, science, and engineering, 2) an ability to design and conduct experiments, as well as to analyze and interpret data, and 3) an ability to design a system, component, or process to meet desired needs within realistic constraints 
such as economic, environmental, health, and safety. The laboratory modules described in this paper will be implemented and assessed during Spring semester 2011. An assessment plan, aligned to the learning outcomes in biomaterials science and the ABET outcomes provided above, is also presented in this paper.

\section{Laboratory Activity: Design of Composites for Bone Replacement}

\subsection{Introduction}

This laboratory will be utilized in our freshman engineering laboratory during Spring 2011. It is intended as an introduction to material science and the use of materials in medicine. Bioactive ceramics such as hydroxyapatite are widely used as bone void fillers. The use of these materials has increased recently due to the surge in osteoporotic fractures in the aging population (5). However, the brittle nature of ceramics limits their use in weightbearing scenarios. Thus, researchers have begun to investigate the reinforcement of

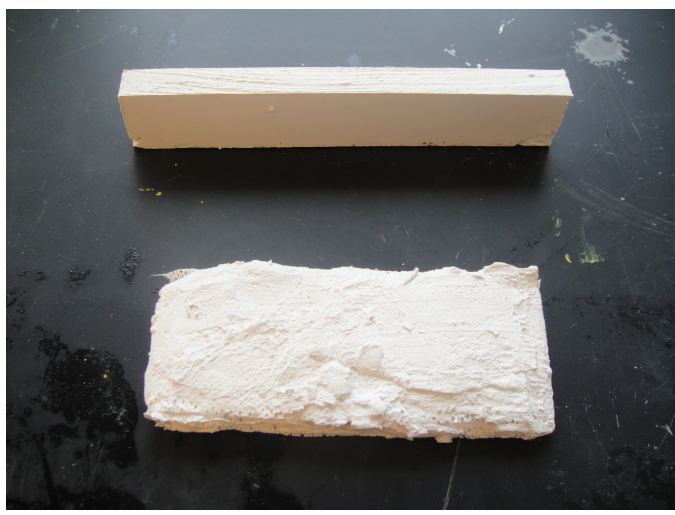

Figure 1. Fiber-reinforced (top) and laminar (bottom) calcium sulfate composites.

such bioceramics with polymeric components (6-8). Here, students will have the opportunity to design their own fiber-reinforced or laminar ceramic-polymer composites for bone replacement (Figure 1) and characterize the mechanical properties.

In this activity, the materials typically used for bone replacement were substituted with cost-effect equivalents. For instance, the ceramic phase employed in this activity is calcium sulfate hemihydrate (plaster of Paris), which substitutes for the more commonly used hydroxyapatite cements. In the fiber-reinforced composites, nylon and polyester string of varying diameters was used instead of sutures (9) or silk fibers (10). For layered composites, a sheet of flexible nylon mesh fabric can substitute for the costly resorbable meshes that have been studied $(11,12)$.

The project, spanning two weeks, has an open-ended structure because it requires students to design their own material combination to maximize mechanical performance. Students will begin by measuring the toughness and strength of calcium sulfate rods, as well as the individual polymeric components. Class discussions will focus on the mechanics of composites and the rule of mixtures. Armed with this information, each group will choose how to reinforce the ceramic matrix. Groups who choose fiber-reinforcement will select the diameter, length and orientation of the discontinuous phase. Those who choose to build the laminar composites will select the orientation and thickness of the layers. After composite assembly, the flexural strength and toughness will be measured with a three-pointbend test (13). An element of competition will also be integrated into the project 
with the group designing the composite with the highest flexural toughness earning the students an automatic A on the lab report. A good grade can also be earned by writing a strong report.

\title{
2.2 Materials
}

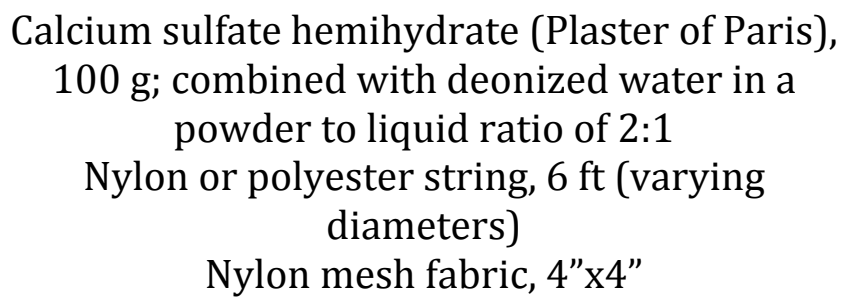

\author{
Mechanical testing machine, \\ capable of three-point bend \\ and tensile modes \\ Rectangular molds \\ Mold release spray
}

\subsection{Procedure}

During the first $2 \frac{1}{2}$ hour lab period, the strength of individual components (string, mesh, and ceramics) are tested. Each component will be tested by two groups and then the data will be shared among the students. The calcium sulfate ceramic is tested in a three point flexural mode (13), while the strings and fabric are loaded under tension (14). Load-displacement data is recorded by the mechanical testing system. Students are responsible for converting the data to stress-strain values. Flexural strength and toughness are calculated for the ceramic and the tensile moduli are calculated for the polymeric materials. Based on the results, students are also required to submit a memo describing their projected composite design. It is expected that they will choose the toughest polymer component for their design. Variables such as fiber length, orientation, and layered composite attributes will also need to be defined based on class discussions and additional research. The effect of such composite parameters have been described elsewhere (15) and will be covered in class at a level appropriate for freshman.

During the second $2 \frac{1}{2} 2$ hour lab period, students will assemble their composites. The calcium sulfate paste is combined with the polymeric components immediately after wetting. The fiber-reinforced composites will be formed inside rectangular molds, whereas layered composites can be assembled on the lab countertop and cut to a regular shape with scissors prior to hardening. Composites are allowed to harden for 50 minutes at room temperature, and then are subjected to a three-point bend test for quantification of the flexural strength and toughness. The students will general a full laboratory report on the project.

\subsection{Assessment Plan}

This laboratory project was designed to contribute to specific outcomes set forth by ABET for undergraduate chemical engineering students. In addition, the laboratory was designed to achieve learning outcomes in biomaterials science, determined by the course designer. Table 1 lists those outcomes, along with specific skills that are targeted within each outcome. Three different types of output, also identified in Table 1, will be used to assess achievement of these outcomes. First, students will take pre and post-tests consisting of 9 multiple-choice questions, each written to test a particular skill categorized within its outcome. The complete test 
can be found in Appendix A. Average pre and post-test scores will be compared statistically to determine significance of the outcomes. Secondly, student lab reports will be evaluated by the course designer and a faculty member not involved in the course. All indentifying aspects of the reports will be removed and solutions will be evaluated with existing rubrics (16) with respect to various indicators of quality and student understanding using a four-point scale. Thirdly, course evaluations will provide an indirect assessment of the laboratory by asking questions such as "How helpful were the following course materials and activities in achieving the course objectives?" and "What were the best features of this course?"

Table 1

\begin{tabular}{|c|c|c|}
\hline & $\begin{array}{c}\text { Measurable skills within each } \\
\text { outcome or objective: }\end{array}$ & \\
\hline $\begin{array}{l}\text { An ability to apply } \\
\text { knowledge of } \\
\text { mathematics, science, } \\
\text { and engineering } \\
\text { (ABET-A) }\end{array}$ & $\begin{array}{l}\text { Students will demonstrate the ability to } \\
\text { apply fundamental concepts gained } \\
\text { from chemistry, material science, } \\
\text { physics and mathematics. Specifically, } \\
\text { they will demonstrate understanding of } \\
\text { chemistry and physics as it applies to } \\
\text { materials science. }\end{array}$ & $\begin{array}{l}\text { Pre and post- } \\
\text { test questions } \\
1,2,3,5,6,9 \\
\text { (Appendix A); } \\
\text { Laboratory } \\
\text { report } \\
\text { discussion }\end{array}$ \\
\hline $\begin{array}{l}\text { An ability } \\
\text { and cc } \\
\text { experimel } \\
\text { as to anc } \\
\text { interpi } \\
\text { (ABH }\end{array}$ & $\begin{array}{c}\text { Students will demonstrate the ability to } \\
\text { analyze data and evaluate its relevance } \\
\text { to composite design. The design process } \\
\text { will give students practice in } \\
\text { experimental design and analysis of } \\
\text { data. }\end{array}$ & $\begin{array}{l}\text { d post- } \\
\text { lestion } \\
\text { ratory } \\
\text { results } \\
\text { id } \\
\text { ssion; }\end{array}$ \\
\hline $\begin{array}{l}\text { An ability to design a } \\
\text { system, component, } \\
\text { or process to meet } \\
\text { desired needs within } \\
\text { realistic constraints. } \\
\text { (ABET-C) } \\
\end{array}$ & $\begin{array}{c}\text { Students will contrast roles of } \\
\text { component materials in composites; } \\
\text { consider material constraints imposed } \\
\text { by the designer }\end{array}$ & $\begin{array}{l}\text { post- } \\
\text { tions } \\
3,9 ; \\
\text { tory } \\
\text { rt } \\
\text { sion }\end{array}$ \\
\hline $\begin{array}{r}\text { Cultivate st } \\
\text { experienc } \\
\text { knowledge in } \\
\text { biomaterials } \\
\text { metho }\end{array}$ & $\begin{array}{r}\text { The open-ended } \mathrm{r} \\
\text { gives studen } \\
\text { undergraduate rese } \\
\text { increased familia } \\
\text { bioma }\end{array}$ & $\begin{array}{l}\text { Pre and post- } \\
\text { test questions } \\
6 \text { and } 8 ; \\
\text { Course } \\
\text { evaluation; }\end{array}$ \\
\hline $\begin{array}{l}\text { Teach students inter- } \\
\text { relationships } \\
\text { between biomaterial } \\
\text { structure, properties, } \\
\text { and medical device } \\
\text { functionality }\end{array}$ & $\begin{array}{l}\text { Students will understand the effects of } \\
\text { composite structure on its mechanical } \\
\text { properties. They will gain insight into } \\
\text { how new materials can be engineered to } \\
\text { meet evolving healthcare needs. }\end{array}$ & $\begin{array}{l}\text { Pre and post- } \\
\text { test questions } \\
3,6,8 \text {; Course } \\
\text { evaluation; } \\
\text { Laboratory } \\
\text { report } \\
\text { discussion }\end{array}$ \\
\hline
\end{tabular}




\section{Laboratory Activity: Hydrogels for Cartilage Replacement}

\subsection{Introduction}

This laboratory was developed for a senior level elective, Introduction to Biomedical Materials, and will be implemented during Spring 2011. This activity gives students hands-on experience with hydrogels. Named 'Biomaterial of the Month' in 2007 by the Society for Biomaterials, a hydrogel is a three-dimensional water swollen network composed of crosslinked hydrophilic polymer chains (3). In this laboratory, students will prepare hydrogels from poly(vinyl alcohol) (PVA). Polyvinyl alcohol (PVA) was chosen for this activity particular for its safety and ease of preparation. Physically crosslinked hydrogels can be prepared from freeze-thaw cycles of aqueous solutions of PVA (17-19). Researchers who have studied the formation of PVA hydrogels from freeze-thaw cycles (20-24) have found that the mechanical properties can be varied as a function of the polymer molecular weight, concentration of the aqueous solution, and the number of freeze-thaw cycles.

PVA hydrogels have been studied extensively for cartilage repair (24-26). A hydrogel that is developed for this application should behave mechanically in a manner similar to native cartilage, which has a very high unconfined compressive modulus, reported to be between 0.1 to $0.8 \mathrm{MPa}$ (27-29). In this laboratory, students are charged as materials scientists with the task of preparing their own PVA hydrogels for the replacement of degenerated cartilage. However, the procedure for preparing the hydrogels will be open-ended. Based on class discussions and literature research, the students will define the parameters for hydrogel preparation that will maximize compressive stiffness. They will find that increasing polymer concentration and increasing number and duration of freezethaw cycles tends to increase the degree of physical crosslinking in the hydrogels (24) and thus the mechanical properties. The molecular weight of PVA will remain fixed (61,000 g/mol, Sigma Aldrich, Mowiol 10-98) and the hydrogel preparation period will last a maximum of 1 week. Hydrogel preparation will be performed outside of the regularly scheduled class time. However, mechanical characterization will occur in class with supervision of the instructor.

\subsection{Materials}

Polyvinyl alcohol $(61,000 \mathrm{~g} / \mathrm{mol})$

Deionized water with a graduated cylinder

96 well plate

Disposable pipetting device
Freezer, $-20^{\circ} \mathrm{C}$

Mechanical testing system

Oven, $90^{\circ} \mathrm{C}$

Scintillation vial (quantity 2)

\subsection{Hydrogel preparation}

Students will prepare approximately $5 \mathrm{~mL}$ of aqueous PVA solution (concentration to be determined by the students). Appropriate amounts of PVA powder and deionized water are combined in a scintillation vial and left overnight in a $90^{\circ} \mathrm{C}$ oven to dissolve. The polymer solution is then transferred to fill wells of a 96-well plate, which is sealed tightly and subjected the freeze-thaw cycles (duration 
and number to be fixed by the students). After the last thaw, gels are removed and stored in room temperature deionized water until testing (Figure 2).

\subsection{Data acquisition and analysis}

For the mechanical tests, gels will be transferred to a $37^{\circ} \mathrm{C}$ water bath and compressed to $30 \%$ strain at a strain rate of $100 \%$ per minute. Students will convert load-displacement data to stress-strain data and report the average unconfined compressive modulus for the gels. Sample data is shown in Figure 3. The discussion questions in the laboratory report are designed to lead students to getting a 'big

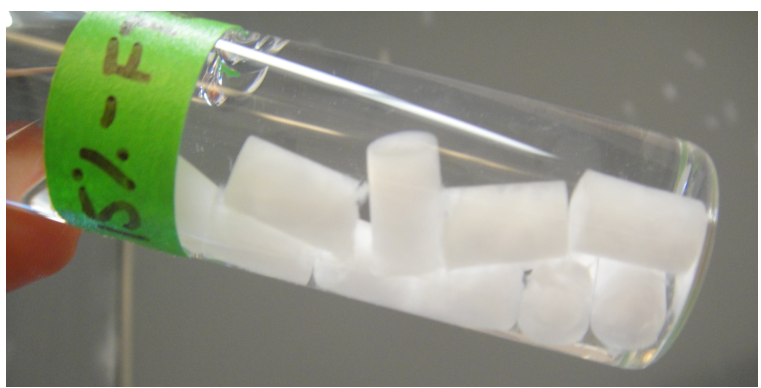

Figure 2. PVA hydrogels formed in a 96well plate. picture' about biomaterials design. For instance, they will need to provide an evaluation of their design. Do their results indicate that the material has the potential to function as a cartilage replacement? In the likelihood that their experimental value for unconfined compressive modulus

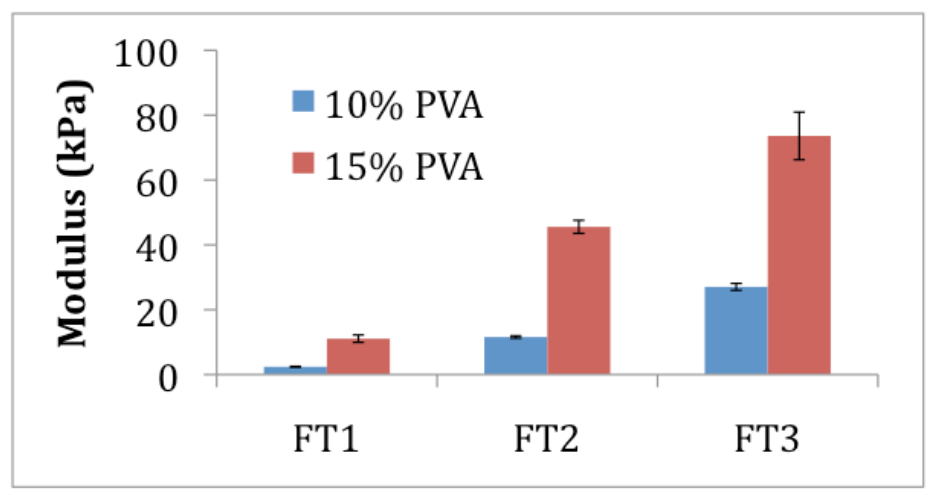

Figure 3. Unconfined compressive modulus of PVA hydrogels formed from 10 and $15 \% \mathrm{w} / \mathrm{v}$ aqueous solutions after 1, 2, and 3 freeze-thaw cycles (FT1, FT2, and FT3, respectively. does not fall in the range for native cartilage, they will propose methods of further enhancing mechanical stiffness of the gels. Obviously, however, the behavior of cartilage is complex and no single mechanical test can be used to definitely evaluate a biomaterial for its

replacement. Students will also be asked to provide additional mechanical parameters that can be measured to further evaluate

the hydrogels. Additional questions focus on ways to optimize of the biological performance of material as a tissue engineering scaffold, such as the incorporation of cell adhesive peptides or enhancement of the porosity. This activity was chosen as a senior-level activity because in future course offerings, we wish to add a second component to the activity. This would involve the analysis of cell-hydrogel interactions for tissue engineering applications, which would be most appropriately conducted at the senior level. 


\subsection{Assessment}

This module will be implemented in Spring 2011. Again, the laboratory activity is designed to contribute to general learning objectives defined by ABET for Chemical Engineering students, as well as more specific objectives within the field of biomaterials science. These are listed in Table 2, along with the measurable skills within each outcome and the student outputs that will be assessed. Pre and posttests, laboratory report quality, and course evaluations will be assessed with the methods described for the previous laboratory. The complete pre and post-test for this laboratory activity can be found in Appendix B.

This newly developed activity will be implemented into a senior-level elective that is currently being taught for the second time. Performance on an exam question directly related to the laboratory will be compared to the previous course offering which used a literature review instead, in attempt to evaluate the impact of the hands-on work on student performance. Again, solutions will be evaluated by the course instructor, as well as a faculty member not involved in the course, using existing rubrics (16). The exam question can be found in Appendix C.

\section{Summary}

This paper presents two experiments that introduce freshman and seniorlevel engineering students the design and evaluation of biomaterials. By designing ceramic-polymer composites for bone substitution and hydrogels for cartilage replacement, students will develop new knowledge in biomaterials science that also contributes to ABET learning outcomes for undergraduate Chemical Engineering courses. Future reports will include assessment results. 
Table 2

\begin{tabular}{|c|c|c|}
\hline Outcome or objective & $\begin{array}{l}\text { Measurable skills within each } \\
\text { outcome or objective }\end{array}$ & $\begin{array}{l}\text { Outputs for } \\
\text { assessment }\end{array}$ \\
\hline $\begin{array}{l}\text { An ability to apply } \\
\text { knowledge of } \\
\text { mathematics, science, and } \\
\text { engineering (ABET-A) }\end{array}$ & $\begin{array}{l}\text { Structure-property relationships } \\
\text { in hydrogels; Polymer physics, } \\
\text { biology and physiology as it } \\
\text { relates to design of tissue } \\
\text { engineering scaffolds. }\end{array}$ & $\begin{array}{l}\text { Pre and post-test } \\
\text { questions 2,4,5 } \\
\text { (Appendix B); } \\
\text { Laboratory report } \\
\text { discussion; Exam } \\
\text { question }\end{array}$ \\
\hline $\begin{array}{l}\text { An ability to design and } \\
\text { conduct experiments, as } \\
\text { well as to analyze and } \\
\text { interpret data (ABET-B) }\end{array}$ & $\begin{array}{c}\text { Students will demonstrate the } \\
\text { ability to analyze mechanical data } \\
\text { characterization data and } \\
\text { evaluate their relevance to the } \\
\text { application. }\end{array}$ & $\begin{array}{c}\text { Pre and post-test } \\
\text { questions 5,6 7; Course } \\
\text { evaluations; Laboratory } \\
\text { report data analysis and } \\
\text { discussion } \\
\end{array}$ \\
\hline $\begin{array}{l}\text { An ability to design a } \\
\text { system, component, or } \\
\text { process to meet desired } \\
\text { needs within realistic } \\
\text { (ABET-C) }\end{array}$ & $\begin{array}{c}\text { Students, when given objectives } \\
\text { and constraints that are relevant } \\
\text { to medicine and healthcare, will } \\
\text { learn how to design a biomaterial } \\
\text { to achieve those goals. }\end{array}$ & $\begin{array}{l}\text { Pre and post-test } \\
\text { questions 5,6,7,8; } \\
\text { Laboratory report } \\
\text { discussion }\end{array}$ \\
\hline $\begin{array}{l}\text { Develop students' ability } \\
\text { to read, analyze, and } \\
\text { critique relevant } \\
\text { literature }\end{array}$ & $\begin{array}{l}\text { Students will research design } \\
\text { parameters for preparation of } \\
\text { PVA hydrogels, analyze and } \\
\text { critique results, and apply } \\
\text { findings to their design. }\end{array}$ & $\begin{array}{c}\text { Laboratory report } \\
\text { discussion; Exam } \\
\text { question }\end{array}$ \\
\hline $\begin{array}{l}\text { Teach students inter- } \\
\text { relationships between } \\
\text { biomaterial structure, } \\
\text { properties, and medical } \\
\text { device functionality }\end{array}$ & $\begin{array}{l}\text { Students will understand the } \\
\text { relationship between crosslink } \\
\text { density, mechanical behavior, and } \\
\text { feasibility as a cartilage } \\
\text { replacement. The understanding } \\
\text { of structure-property } \\
\text { relationships in polymers can be } \\
\text { extended to the development of } \\
\text { materials for other applications. }\end{array}$ & $\begin{array}{l}\text { Pre and post-test } \\
\text { questions 1,2, 4; Exam } \\
\text { question; Laboratory } \\
\text { report discussion }\end{array}$ \\
\hline $\begin{array}{l}\text { Teach students how to } \\
\text { design a biomaterial to } \\
\text { achieve the desired } \\
\text { healing response }\end{array}$ & $\begin{array}{l}\text { Students will apply principles on } \\
\text { wound healing, foreign body } \\
\text { responses, and tissue engineering } \\
\text { to optimization of biomaterials }\end{array}$ & $\begin{array}{l}\text { Pre and post-test } \\
\text { question 7; Laboratory } \\
\text { report discussion }\end{array}$ \\
\hline
\end{tabular}




\section{APPENDIX A \\ Pre-assessment for Material Science Module \\ Professor Vernengo \\ Freshman Clinic II}

1. Everything around us is made out of elements. These elements bond together in different ways, depending on the material. Match the material with the predominant type of bonding that exists in it.

$\begin{array}{ll}\text { Metal } & \text { Covalent } \\ \text { Ceramic } & \text { Ionic } \\ \text { Polymer } & \text { Metallic }\end{array}$

2. Ionic bonds can occur between
a. Two oppositely charged ions
b. Two cations
c. Two anions
d. Two metallic elements

3. What is the difference between a brittle and tough material?

a. A brittle material will rupture into two pieces when a force is applied without significantly deforming first, but a tough material with deform significantly before breaking.

b. A tough material will rupture into two pieces when a force is applied without significantly deforming first, but a brittle material with deform significantly before breaking

c. Brittle materials are always soft, but a tough materials can be hard.

d. Brittle and tough are synonyms.

4. A tensile test can be described by

a. A material specimen is twisted.

b. A material specimen is loaded in such a way that it is shortened.

c. A material specimen is loaded in such a way that it is extended.

d. A material specimen is loaded cyclically so it is shortened then extended.

5. Which of the following schematics illustrates a three-point flexural test?
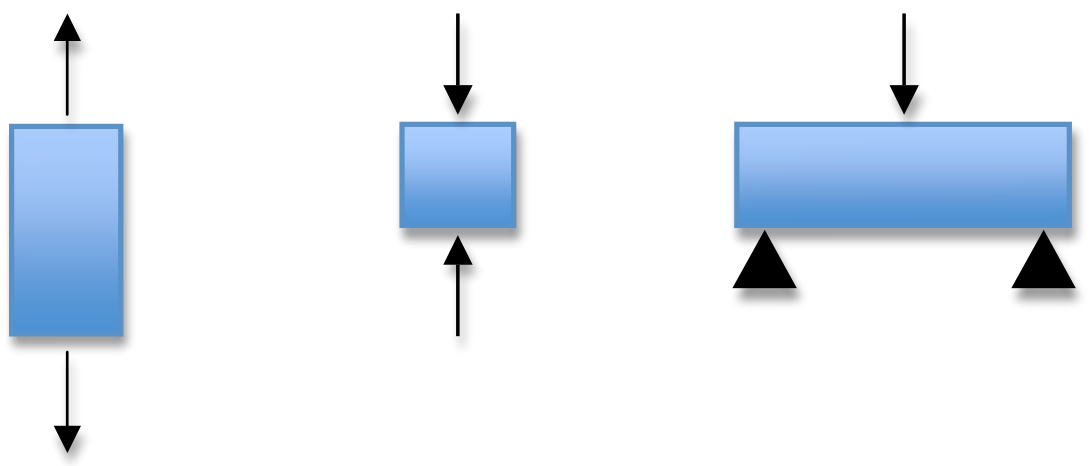
6. Many bone replacements are made out of ceramics. Materials scientists are tasked with designing better bone implants because ceramics are brittle. This means that:

a. When exposed to high forces, a ceramic implant may break catastrophically without deforming first.

b. Ceramics implants will bounce when a person puts weight on it.

c. If you pull on a ceramic implant, it will extend, like silly putty.

d. Ceramics have low melting points, so they can melt when inside the body.

7. Why are mathematical models important in the design process?

a. They keep engineers on their toes by not letting them forget how to do math.

b. They can be used to predict the behavior of an engineered system, helping you to get closer to a successful design before starting your experimental work!

c. You don't have to build an actual prototype if you have a mathematical model, which theoretically predicts the performance of your engineered system.

8. A composite is defined as:

a. A mixture of two metals that exhibits the properties of both components

b. A blend of two ceramics that exhibits the properties of both components

c. A multiphase material that exhibits a significant proportion of the properties of both constituent phases such that a better combination of properties is realized.

d. Any material designed to have superior mechanical properties.

9. Choose the most likely property and material in Table B for the items in Table A.

Table A

\begin{tabular}{|c|c|}
\hline Part & Material \\
\hline Headlight lens & \\
\hline Light bulb filament & \\
\hline Dashboard & \\
\hline Coffee mug & \\
\hline
\end{tabular}

Table B

MATERIAL

1. Polymer

2. Metal

3. Ceramic 


\section{APPENDIX B \\ Pre and post-test for Introduction to Biomedical Materials \\ Laboratory Activity}

1. In polymers, a crosslink is:

a. A covalent, ionic, and physical connection that bonds one polymer chain to another, forming a "net" of polymer chains.

b. A way of knitting two polymer fibers together to make a single stronger fiber.

c. Combing two different types of polymers to get one substance that is a cross between them with intermediate properties.

d. The covalent bond that exists between two carbon atoms in a single polymer chain.

2. Crosslinks make a polymer material
a. Insoluble in a solvent
b. Weaker
c. Thinner
d. Colorful

3. Someone hands you an object and asks you to describe its material properties. What is meant by material properties?
a. Color
b. Electrical conductivity
c. Hardness
d. Surface roughness
e. All of the above

4. To INCREASE the tensile and compressive strength of a polymeric implant you may try:

a. Decreasing its molecular weight

b. Decrease its crystallinity

c. Increase the degree of crosslinking between polymer chains

d. Heating it to body temperature

5. You want to design a hydrogel for tendon placement. The best plan is to:

a. Subject it to different forces and see how it responds.

b. Choose a minimum value for tensile strength, and manipulate the polymer structure until you reach that value

c. Subject it to different forces and compare its response to a tendon. Keep manipulating its structure until you achieve similar response to tendon.

d. Ensure you have designed your hydrogel to achieve maximum compressive strength you feel you can, this way you are fairly confident it will never rupture when loaded. 
6. You are asked with designing an improved electrospun scaffold for cardiac tissue engineering. Where is a good place to start?

7. You are designing a PVA-based tissue engineering scaffold for cartilage repair. Based on recent research advances, what are some elements that can be included in the hydrogel to promote a healing response?

8. You are a scientist working at Medtronic. What is an example of a realistic constraint that may be imposed on you while trying to engineer a new biomaterial?
a. Your new material must withstand at least 100,000 cyclic loads over its expected lifetime.
b. Use only FDA approved materials.
c. It must be resorbed completely within 2 years.
d. It must cost less than $\$ 10$ per unit to manufacture.
e. All of the above.
f. B and C only 


\section{APPENDIX C}

\section{EXAM QUESTION - INTRODUCTION TO BIOMEDICAL MATERIALS SPRING 2010 AND 2011}

Heart disease is a leading cause of death in the western world. A common treatment is coronary bypass surgery, where a doctor removes a blood vessel from the chest or leg and attaches one end to the aorta (the large artery exiting the heart) and the other end to the artery below the clog (see picture below, reproduced from the American Heart Association). The transplanted blood vessel is called a graft. The idea is to create a new channel to the heart.

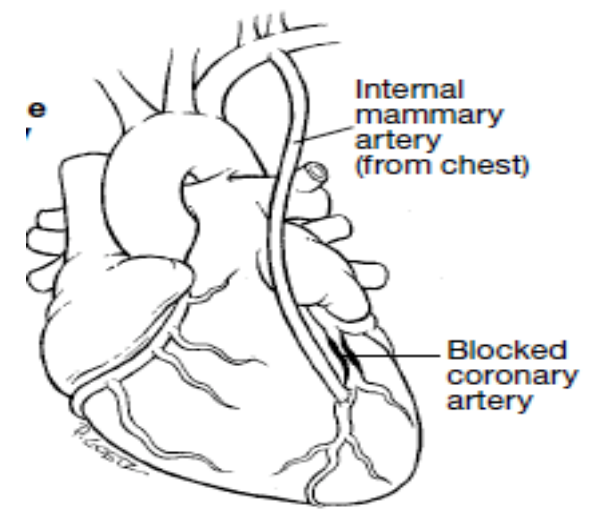

a) Cardiac tissue is largely composed of elastin and collagen. Given this information, can you predict (in words, picture, or a graph) how cardiac tissue would behave under tensile loading?

b) Development of a synthetic graft material would eliminate the morbidity associated with using the patient's own tissue as the graft. Poly(vinyl alcohol) (PVA) is a hydrophilic material that has been proposed as a material for synthetic blood vessel. Describe the design parameters you can vary in PVA hydrogel preparation that would help you to attain a mechanical equivalent to natural cardiac tissue. 


\section{References}

1. Williams D. The Williams Dictionary of Biomaterials. Liverpool: Liverpool University Press; 1999.

2. Moss A. Use of Selected Medical Device Implants in the United States. Hyattsville, MD: National Center of Health Statistics; 1988 Contract No.: Document Number|.

3. Ratner B, Hoffman AS, Schoen FJ, Lemons JE. Biomaterials Science: A Multidisciplinary Endeavor. Biomaterials Science: A Introduction to Materials in Medicine. San Diego: Elsevier Academic Press; 2004. p. 1-9.

4. Black J, Shalaby SW, LaBerge M. Biomaterials Education: An Academic Viewpoint. Journal of Applied Biomaterials. 1992;3:231-6.

5. Cheung W, Qin L, Tam KF, Siu W, Leung KS. Enhancement of Osteoporotic Bone Using Injectable Hydroxyapatite in OVX Goats Evaluated by Multi-imaging Modalities In: Qin L, Genant HK, Griffith JF, Leung KS, editor. Advanced Bioimaging Technologies in Assessment of the Quality of Bone and Scaffold Materials. Heidelberg, Germany: Springer; 2007.

6. $\mathrm{Xu} \mathrm{H}$, Simon CG. Fast setting calcium phosphate-chitosan scaffold:mechanical properties and biocompatibility. Biomaterials. 2005;26:1337-48.

7. Converse G, Yue W, Roeder RK. Processing and tensile properties of hydroxyapatite-whisker-reinforced polyetheretherketone. Biomaterials. 2007;28:927-35. 8. Schnieders J, Gbureck U, Thulb R, Kissel T. Controlled release of gentamicin from calcium phosphate_-poly(lactic acid-co-glycolic acid) composite bone cement. Biomaterials. 2006;27.

9. $\mathrm{Xu} \mathrm{H}$, Quinn, JB Calcium phosphate cement containing resorbable fibers for short-term reinforcement and macroporosity. Biomaterials. 2002;23:193-202.

10. LI S, Liu B, Cheng J, Hu J Shiqun Li. Composite cement of magnesium-bearing phosphoaluminate-hydroxyapatite reinforced by treated raw silk fiber. Cement and Concrete Composites. 2008;30(4):347-52.

11. Tormala P, inventor Layered Surgical Biocomposite Material. United States. 1992.

12. Dumican B, inventor America Cyanamid Company, assignee. Surgical Repair Mesh. United States. 1987.

13. ASTM. ASTM C1161 - 02c(2008)e1 Standard Test Method for Flexural Strength of Advanced Ceramics at Ambient Temperature.

14. ASTM. ASTM D2256 / D2256M - 10e1 Standard Test Method for Tensile Properties of Yarns by the Single-Strand Method.

15. Callister W. MATERIALS SCIENCE AND ENGINEERING AN INTRODUCTION: John Wiley \& Sons Inc; 1995.

16. Newell J, Dahm KD, Newell HL. Rubric development and inter-rater reliability issues in assessing learning outcomes. Chemical Engineering Education. 2002;36:212-5. 17. Peppas N, Merrill EW. Crosslinked poly (vinyl alcohol) hydrogels as swollen elastic networks. Journal of Applied Polymer Science. 1977;21:1763-77.

18. Thomas J, Lowman A, Marcolongo M. Novel associated hydrogels for nucleus pulposus replacement. J Biomed Mater Res Part A. 2003;67:1329-37. 
19. Hassan C, Stewart JE, Peppas NA. Diffusional characteristics of freeze/thawed poly(vinyl alcohol) hydrogels: Applications to protein controlled release from multilaminate devices. European Journal of Pharmaceutics and Biopharmaceutics 2000;49:161-5.

20. Stauffer S, Peppas NA. Poly(vinyl alcohol) hydrogels prepared by freezingthawing cyclic processing. Polymer. 1992;33(18):3932-6.

21. Urushizaki F, Yamagushi H, Nakamura K, Numajiri S, Sugibayashi, K, Morimoto Y. Swelling and mechanical properties of poly(vinyl alcohol) hydrogels. International Journal of Pharmaceutics 1990;58:135-42.

22. Hickey A, Peppas NA. Mesh size and diffusive characteristics of semicrystalline poly (vinyl alcohol) membranes prepared by freezing/thawing techniques. Journal of Membrane Science 1995;107:229-37.

23. Peppas N, Scott JE. Controlled release from poly (vinyl alcohol) gels prepared by freezing-thawing processes. Journal of Controlled Release 1992;18:95-100.

24. Stammen J, Williams S, Ku DN, Gulderg RE. Mechanical properties of a novel PVA hydrogel in shear and unconfned compression. Biomaterials. 2001;22:799-806.

25. Spiller K, Laurencin SJ, Lowman AM. Characterization of the Behavior of Porous Hydrogels in Model Osmotically-Conditioned Articular Cartilage Systems. Journal of Biomedical Materials Research Part B: Applied Biomaterials. 2009;90B:752-9.

26. Kobayashi M, Chang YS, Oka M Masanori Kobayashia. A two year in vivo study of polyvinyl alcohol-hydrogel (PVA-H) artificial meniscus Biomaterials. 2005;26(16):3243-8.

27. Korhonen R, Laasanen M, Toyras J, Rieppo J, Hirvonen H, Helminen H, Jurvelin JS. Comparison of the equilibrium response of articular cartilage in unconfined compression, confined compression, and indentation Journal of Biomechanics. 2002;35:903-9.

28. Jurvelin J, Buschmann MD, Hunziker EB. Optical and mechanical determination of Poisson's ratio of adult bovine humeral articular cartilage. Journal of Biomechanics. 1997;30(3):235-41.

29. Demarteau O, Pillet L, Inaebnit A, Borens O, Quinn TM. Biomechanical characterization and in vitro mechanical injury of elderly human femoral head cartilage: comparison to adult bovine humeral head cartilage. Osteoarthritis and cartilage / OARS, Osteoarthritis Research Society. 2006;14(6):589-396. 